\title{
Penggunaan Radiofarmaka Untuk Diagnosa Dan Terapi Di Indonesia Dan Asas Keamanan Penggunaan Obat
}

\author{
N. Elly Rosilawati, I. Nasution dan Tri Wahyu Murni \\ ellyrosilawati@gmail.com \\ Magister Hukum Kesehatan \\ Universitas Katolik Soegijapranata Semarang
}

\begin{abstract}
ABSTRAK
Tuntutan masyarakat terhadap kualitas pelayanan kesehatan meningkat sejalan dengan kemajuan ilmu pengetahuan, teknologi dan globalisasi. Salah satu strategi dalam meningkatkan derajat kesehatan adalah mengutamakan pelayanan yang berkualitas kepada setiap masyarakat. Sumber tenaga kesehatan dan sarana pelayanan kesehatan paling berperan dalam peningkatan kualitas. Pemerintah terus-menerus membangun sarana pelayanan kesehatan yang memenuhi standar pelayanan kesehatan baik kualitas maupun kuantitasnya termasuk sumber daya manusianya.

Saat ini dengan perkembangan ilmu dan teknologi kedokteran, pemeriksaan penunjang diagnostik kesehatan telah berkembang pula dengan pesat. Salah satu jenis pemeriksaan penunjang yang cukup pesat perkembangannya adalah Ilmu Kedokteran Nuklir. Teknologi ini memanfaatkan sumber radiasi terbuka yang berasal dari disintegrasi inti radionuklida (radioisotop) buatan untuk tujuan diagnostik melalui pemantauan proses fisiologi dan biokimia, pengobatan dan juga penelitian di bidang kedokteran. Penggunaan dan jenis senyawa bertanda radionuklida (radiofarmaka) dalam bidang Kedokteran Nuklir di Indonesia berkembang secara terus-menerus. Sediaan radiofarmaka tidak berbeda dengan obat parental konvensional dalam persyaratan kemurnian, keamanan dan manfaatnya. Agar sesuai dengan asas keamanan penggunaan obat maka semua produk radiofarmaka harus melalui perlakuan kendali mutu yang ketat baik dalam proses pembutan produksi maupun peredarannya.

Metode penelitian yang digunakan adalah penelitian deskriptif dengan pendekatan yuridis normatif. Tehnik pengumpulan data menggunakan studi pustaka untuk mencari data sekunder terdiri dari bahan hukum primer, sekunder dan tersier. Sistematika penulisan terdiri dari enam bab untuk memperjelas ruang lingkup dan cakupan permasalahan yang diteliti.

Berdasarkan penelitian mengenai sebab akibat antara hubungan penggunaan radiofarmaka untuk diagnosa dan terapi di Indonesia dan asas keamanan penggunaan obat, bahwa pemerintah belum mengatur mengenai produksi dan peredaran radiofarmaka di Indonesia. Regulasi untuk sediaan radiofarmaka sangatlah diperlukan mengingat radiofarmaka juga merupakan sediaan farmasi sehingga adanya perlindungan hukum bagi pasien bahwa obat yang digunakan memiliki mutu, keamanan dan kemanfaatan sesuai dengan peraturan yang telah ditetapkan. hal ini tentunya sangat penting agar sesuai dengan asas keamanan penggunaan obat.

(Kata kunci : Penggunaan Radiofarmaka untuk diagnosa dan terapi di Indonesia, Keamanan Pemakaian Obat)
\end{abstract}




\section{PENDAHULUAN}

\section{A. Latar Belakang}

Pokok-pokok rencana pembangunan kesehatan menuju Indonesia Sehat 2010, menggariskan arah pembangunan kesehatan yang mengedepankan paradigma sehat. Tujuan pembangunan kesehatan menuju Indonesia Sehat 2010 antara lain meningkatkan kesadaran, kemauan dan kemampuan hidup sehat dan memiliki akses terhadap pelayanan kesehatan bermutu secara adil dan merata. Untuk mencapai hal tersebut pembangunan kesehatan bertujuan meningkatkan kesadaran, kemauan dan kemampuan hidup sehat bagi setiap orang agar terwujud derajat kesehatan masyarakat yang setinggi-tingginya. Pembangunan kesehatan tersebut merupakan upaya seluruh potensi bangsa Indonesia, baik masyarakat, swasta maupun pemerintah.

Seperti kita ketahui bahwa kesehatan merupakan hak asasi setiap manusia. Setiap manusia akan berusaha untuk mendapatkan pelayanan kesehatan yang sebaik mungkin bagi dirinya. Dari segi hukum kesehatan mencakup hak atas kehidupan, hak atas pengakhiran kehidupan, hak atas keutuhan tubuh serta hak atas kehormatan dan integritas tubuh dan jiwa.

Pada dasarnya setiap orang bertanggung jawab penuh atas kesehatannya sendiri. Secara medis orang sakit akan berobat ke dokter atau tenaga medis, dan sarana kesehatan. Para dokter akan berusaha mengobati pasien yang menderita kesakitan melalui beberapa tahap, seperti anamnesa atau mencari keterangan, pemeriksaan fisik, pemeriksaan diagnostik, menentukan diagnosa, menentukan perkembangan penyakit, dan terakhir adalah memberikan terapi atau obat. Namun seringkali seorang dokter dalam menentukan diagnosa penyakit pasien memerlukan pemeriksaan tambahan yang disebut pemeriksaan diagnostik, selain pemeriksaan fisik yang dilakukan di tempat pemeriksaan.

Saat ini dengan perkembangan ilmu dan teknologi kedokteran, pemeriksaan penunjang diagnostik kesehatan telah berkembang dengan pesat. Salah satu jenis pemeriksaan penunjang yang cukup pesat perkembangannya adalah Ilmu Kedokteran Nuklir.

Ilmu Kedokteran Nuklir merupakan salah satu cabang ilmu kedokteran yang mandiri terpisah dari spesialisasi lain. Teknologi ini memanfaatkan sumber radiasi terbuka yang berasal dari disintegrasi inti radionuklida (radioisotop) buatan untuk tujuan diagnostik melalui pemantauan proses fisiologi dan biokimia, pengobatan dan juga penelitian di bidang kedokteran. Pelayanan kedokteran Nuklir merupakan pelayanan yang bersifat multidisipliner, karena dalam pelaksanaannya melibatkan berbagai disiplin ilmu yaitu ilmu kedokteran, instrumentasi dan radiofarmasi.

Pemanfaatan radionuklida dalam bidang kedokteran nuklir dapat digunakan untuk tujuan diagnostik in-vivo, invitro dan terapi. Pelayanan diagnostik in-vivo adalah pemeriksaan radionuklida dan/atau radiofarmaka, kemudian dengan menggunakan alat pencacah atau kamera gamma dilakukan pengamatan terhadap radionuklida dan/atau radiofarmaka tersebut selama dalam tubuh. Pelayanan diagnostik in-vitro adalah pemeriksaan yang dilakukan terhadap spesimen yang diperoleh dari pasien menggunakan tehnik radioimmuno assay atau immunoradiometric assay. Terapi beberapa penyakit tertentu sudah dapat dilakukan dengan menggunakan radionuklida atau lebih dikenal dengan radiasi internal.

Penggunaan dan jenis radiofarmaka dalam bidang Kedokteran Nuklir di Indonesia berkembang secara terus-menerus. Radiofarmaka biasanya diformulasi sebagai sediaan injeksi yang steril dan apirogenik, diberikan kepada pasien untuk tujuan diagnostik atau terapi. Dalam keadaan ini radiofarmaka tidak berbeda dengan obat parental konvensional dalam persyaratan kemurnian, keamanan dan manfaatnya. Dengan demikian, semua produk radiofarmaka harus melalui perlakuan kendali mutu yang ketat. Standar mutu dan standar kemurnian harus ditetapkan dan produk ini harus diuji untuk menjamin kesesuaiannya terhadap standar tersebut. 
Perbedaan utama antara radiofarmaka dengan obat konvensional terletak pada umur pakai produk radioaktif yang sangat pendek (singkat) dibandingkan dengan sediaan injeksi konvensional biasanya beberapa tahun. ${ }^{1}$

Undang- Undang Republik Indonesia Nomor 36 Tahun 2009 tentang Kesehatan disebut UU Kesehatan merupakan kaidah hukum yang mengatur mengenai hukum kesehatan masyarakat secara umum dan mengatur beberapa aspek dalam hukum kedokteran, pengamanan sediaan farmasi dan alat kesehatan dan perbekalan kesehatan.

Sebagai pelaksanaan Undang-Undang Republik Indonesia Nomor 23 Tahun 1992 tentang Kesehatan adalah Peraturan Pemerintah Republik Indonesia Nomor 72 Tahun 1998 tentang Pengamanan Sediaan Farmasi dan Alat Kesehatan merupakan upaya dalam pembangunan kesehatan yang dilakukan untuk melindungi masyarakat dari bahaya yang disebabkan oleh penggunaan sediaan farmasi dan alat kesehatan yang tidak tepat. PP 72 mengatur pula mengenai persyaratan mutu, keamanan dan kemanfaatan, penyaluran dan penyerahan sediaan farmasi. PP 72 sebagai peraturan pelaksana dari Undang-Undang Republik Indonesia Nomor 23 Tahun 1992 tentang Kesehatan masih tetap berlaku walaupun telah terbit Undang-Undang Kesehatan yang baru. Hal ini dinyatakan pada Ketentuan Peralihan di dalam Undang-Undang Republik Indonesia Nomor 36 Tahun 2009 tentang Kesehatan pada Pasal 203 bahwa: "Pada saat Undang-Undang ini berlaku, semua peraturan pelaksanaan Undang-Undang Nomor 23 Tahun 1992 tentang Kesehatan dinyatakan masih tetap berlaku sepanjang tidak bertentangan dengan ketentuan dalam Undang-Undang ini”.

Untuk mengawasi pemanfaatan tenaga nuklir (termasuk pengawasan penggunaan sumber radiasi di Kedokteran Nuklir) telah diatur dalam Undang-Undang Republik Indonesia Nomor 10 Tahun 1997 tentang Ketenaganukliran, oleh karena sifat tenaga nuklir selain dapat memberikan manfaat juga dapat menimbulkan bahaya radiasi sehingga setiap kegiatan yang berkaitan dengan tenaga nuklir harus diawasi dan diatur oleh Pemerintah.

Asas keamanan penggunaan obat adalah memberikan jaminan keamanan dalam penggunaan, pemakaian dan pemanfaatan obat yang dikonsumsi atau digunakan oleh pasien. Hal ini tersirat dalam Peraturan Pemerintah Republik Indonesia Nomor 72 Tahun 1998 tentang pengamanan sediaan farmasi dan alat kesehatan, pasal 2 berbunyi: "Sediaan farmasi dan alat kesehatan yang diproduksi dan/atau diedarkan harus memenuhi persyaratan mutu, keamanan, dan kemanfaatan".

Mengingat bahwa radiofarmaka juga merupakan suatu obat yang sangat bermanfaat dalam bidang kesehatan khususnya pelayanan Kedokteran Nuklir dalam mendiagnosis dan pengobatan suatu penyakit, dan mengingat belum diatur secara spesifik dalam Undang-Undang maupun Peraturan Pemerintah. Selain itu dengan mempertimbangkan keselamatan konsumen dalam hal ini pasien dari efek radiasi yang ditimbulkannya, serta adanya jaminan bahwa obat yang digunakan oleh pasien memiliki mutu, keamanan dan kemanfaatan sesuai dengan peraturan yang telah ditetapkan maka perlu dipikirkan adanya peraturan khusus untuk mengawasi pengggunaan sediaan radiofarmaka yang meliputi proses pembuatan (produksi), dan peredaran, sehingga sediaan radiofarmaka yang beredar di Indonesia tidak melanggar asas keamanan penggunaan obat. Sehingga penulis menuangkan judul tesis "PENGGUNAAN RADIOFARMAKA UNTUK DIAGNOSA DAN TERAPI DI INDONESIA DAN ASAS KEAMANAN PENGGUNAAN OBAT"

\footnotetext{
${ }^{1}$ Batan, Pedoman Tentang Cara Pembuatan Radiofarmaka Yang Baik, Serpong, Batan Tenaga Nuklir Nasional, 2008, hlm1. 


\section{B. Perumusan Masalah}

Berdasarkan latar belakang yang telah diuraikan di atas, maka yang menjadi perumusan masalah dalam penelitian ini adalah :

\section{“Apakah Penggunaan Radiofarmaka Untuk Diagnosa dan Terapi di Indonesia Sudah Sesuai dengan Asas Keamanan Penggunaan Obat?}

Dengan perumusan masalah di atas, penulis dalam penelitian ini akan membatasi hal-hal yang diidentifikasi sebagai berikut:

1. Apakah yang dimaksud dengan Penggunaan Radiofarmaka untuk Diagnosa dan Terapi di Indonesia

2. Apakah yang dimaksud dengan Asas Keamanan Penggunaan Obat?

3. Apakah Penggunaan Radiofarmaka Untuk Diagnosa dan Terapi di Indonesia Sudah Sesuai dengan Asas Keamanan Penggunaan Obat?

\section{METODOLOGI PENELITIAN}

\section{A. Metode Pendekatan}

Dalam penulisan penelitian ini metode pendekatan yang digunakan adalah metode penelitian hukum normatif ${ }^{2}$ yaitu dengan meneliti pada data sekunder bidang hukum yang ada sebagai data kepustakaan dengan menggunakan metode berpikir deduktif dan kriterium kebenaran koheren.

\section{B. Sifat Penelitian}

Sifat penelitian yang digunakan adalah secara deskriptif analitis, yaitu memberi gambaran tentang hal-hal yang berkaitan dengan penggunaan radiofarmaka untuk diagnosa dan terapi di hubungkan dengan pengaturan sediaan farmasi dan ketentuan kefarmasian tentang penyediaan dan asas keamanan penggunaan obat secara menyeluruh dan sistematis, kemudian terhadap permasalahan yang timbul dilakukan analisis dengan menggunakan interpretasi atau penafsiran hukum.

\section{Jenis Data}

Jenis data yang dipergunakan dalam penelitian ini, yaitu data sekunder. yaitu data yang diperoleh peneliti dari penelitian kepustakaan dan dokumentasi, yang merupakan hasil penelitian dan pengolahan orang lain, yang sudah tersedia dalam bentuk buku-buku atau dokumentasi yang biasanya disediakan di perpustakaan umum atau perpustakaan milik pribadi. ${ }^{3}$

\section{Metode Pengumpulan Data}

Oleh karena data yang dipergunakan dalam penelitian ini adalah data sekunder yang bersifat kualitatif, maka metode pengumpulan data yang dipergunakan adalah studi kepustakaan.

\section{E. Metode Analisis Data}

Metode analisis data yang digunakan terhadap data yang ada adalah pendekatan kualitatif, parameter statistik tidak digunakan dalam menganalisa data yang ada dalam pendekatan secara kualitatif ini.

\footnotetext{
${ }^{2}$ Soejono Soekanto, et al, Penelitian Hukum Normatif, Jakarta Rajawali, Yahun 1995, hlm.15

${ }^{3}$ Hilman Hadikusuma, Op Cit, hlm.65. 
Berdasarkan uraian mengenai metode penelitian tersebut di atas, dapat dijelaskan bahwa spesifikasi penelitian yang digunakan dalam penelitian tesis ini adalah deskriptif analitis. Sehingga metode pendekatan yang adekuat digunakan dalam penelitian tesis ini adalah metode pendekatan yuridis normatif. Selanjutnya agar analisis yang diperoleh dari penelitian ini dapat diuji keabsahannya dan dapat diandalkan hasil penelitiannya, yaitu mencari hubungan antara Penggunaan Radiofarmaka untuk Diagnosa dan Terapi di Indonesia dan Asas Keamanan Penggunaan Obat, maka metode analisis data yang digunakan adalah metode kualitatif normatif.

\section{HASIL PENELITIAN DAN PEMBAHASAN}

Sejalan dengan perkembangan ilmu pengetahuan dalam penggunaan teknologi modern yang sangat cepat, pemakaian zat radioaktif dan atau sumber radiasi lainnya juga makin meluas. Radiasi dalam berbagai bentuk seperti sinar-x, sinar gamma, beta ataupun alfa mempunyai manfaat dalam bidang kedokteran baik untuk kepentingan diagnosis maupun untuk pengobatan berbagai macam penyakit.

Namun demikian walaupun pemakaian zat radioaktif dan atau sumber radiasi lainnya mengandung nilai yang positif bagi kehidupan manusia, namun ternyata radiasi juga dapat menimbulkan risiko bahaya yang dapat terjadi baik terhadap manusia maupun terhadap harta dan benda serta lingkungan, oleh karenanya pemanfaatan radiasi harus dilakukan dengan hatihati.

\section{A. Penggunaan Radiofarmaka Untuk Diagnosa Dan Terapi Di Indonesia}

Pada dasarnya setiap orang bertanggung jawab penuh atas kesehatannya sendiri. Secara medis orang sakit akan berobat ke dokter atau tenaga medis, dan sarana kesehatan. Para dokter akan berusaha mengobati pasien yang menderita kesakitan melalui beberapa tahap, seperti anamnesa atau mencari keterangan, pemeriksaan fisik, pemeriksaan diagnostik, menentukan diagnosa, menentukan perkembangan penyakit, dan terakhir adalah memberikan terapi atau obat.

Seringkali seorang dokter dalam menentukan diagnosa penyakit pasien memerlukan pemeriksaan tambahan yang disebut pemeriksaan diagnostik, selain pemeriksaan fisik yang dilakukan di tempat pemeriksaan. Saat ini dengan perkembangan ilmu dan teknologi kedokteran, pemeriksaan penunjang diagnostik kesehatan telah berkembang dengan pesat. Salah satu jenis pemeriksaan penunjang yang cukup pesat perkembangannya adalah Ilmu Kedokteran Nuklir.

\section{Manfaat Radiofarmaka Untuk Tujuan Diagnostik dan Terapi di Kedokteran Nuklir}

Kedokteran nuklir adalah teknologi kedokteran yang menggunakan senyawa radioaktif sumber terbuka untuk mempelajari perubahan fisiologi dan biokimia sehingga dapat digunakan untuk tujuan diagnostik, terapi dan penelitian kedokteran. Pada kedokteran nuklir, radionuklida dapat dimasukan ke tubuh pasien (studi in vivo) ataupun hanya direaksikan dengan bahan biologis, antara lain darah, cairan lambung, dan urin yang diambil dari tubuh pasien, yang lebih dikenal sebagai studi in-vitro. Pada studi in-vivo, setelah radiofarmaka dimasukan ke tubuh pasien dengan cara parental, maka akan diperoleh informasi berupa citra atau gambar organ dengan bantuan peralatan gamma kamera SPECT atau kamera positron (PET).

Melalui kedokteran Nuklir, informasi tentang keadaan organ pasien dan diagnosis penyakit pasien dapat diperoleh secara akurat dalam waktu relatif pendek. Diagnosis dengan teknik kedokteran nuklir menggunakan radiofarmaka digolongkan pada diagnosis secara non invasif, sehingga pasien tidak merasa sakit atau tetap merasa nyaman. Kemampuan untuk mengamati fungsi organ sangat sensitif, sehingga tehnik kedokteran nuklir merupakan pemeriksaan diagnotik yang dapat diandalkan. 
Pemeriksaan kedokteran nuklir banyak membantu dalam menunjang diagnosis berbagai penyakit. Yakni penyakit jantung koroner, penyakit kelenjar tiroid, gangguan fungsi ginjal, hati dan paru, menetukan tahapan penyakit kanker dengan mendeteksi penyebarannya pada tulang, mendeteksi perdarahan pada saluran pencernaan makanan dan menentukan lokasinya, serta masih banyak lagi yang dapat diperoleh dari diagnose dengan penerapan teknologi nuklir yang pada saat ini sangat berkembang pesat.

Pemanfaatan sumber radiasi pengion dalam bentuk radioisotop (radionuklida) dan senyawa bertanda radioaktif (radiofarmaka) di Indonesia telah lama dimulai yakni sejak tahun 1965. Sampai dengan saat ini penggunaan dan jenis radiofarmaka yang digunakan dalam bidang kedokteran khususnya kedokteran Nuklir menunjukan gejala yang terus berkembang dan meningkat seiring dengan kemajuan teknologi instrumentasi modern yang telah dicapai sebagai modalitas untuk Kedokteran Nuklir seperti gamma kamera (SPECT) dan kamera positron (PET). Selain itu dengan banyaknya fasilitas pelayanan kedokteran nuklir yang di bangun di beberapa rumah sakit di Indonesia menyebabkan makin meningkatnya penggunaan sediaan radiofarmaka.

Dalam Undang-Undang Republik Indonesia Nomor 10 Tahun 1997 tentang Ketenaganukliran, pada Pasa 11 ayat (4) berbunyi Pemanfaatan adalah kegiatan yang berkaitan dengan tenaga nuklir yang meliputi penelitian, pengembangan, penambangan, pembuatan, produksi, pengangkutan, penyimpanan limbah radioaktif untuk meningkatkan kesejahteraan rakyat. Hal ini sesuai dengan penggunaan senyawa bertanda radioaktif (radiofarmaka) sebagai obat adalah sejalan dengan upaya pemerintah dalam pembangunan kesehatan yang bertujuan untuk meningkatkan derajat kesehatan. Zat radioaktif menurut Undang-undang yang sama ayat (9) pada pasal yang sama menyatakan setiap zat yang memencarkan radiasi pengion dengan aktivitas jenis lebih besar dari pada $70 \mathrm{kBq} / \mathrm{kg}$ (2 nCi/g).

Berdasarkan pasal di atas bahwa tujuan akhir dari pemanfaatan radiasi berupa senyawa bertanda radionuklida (radiofarmaka) adalah untuk mensejahterakan rakyat. Hal ini dikarenakan radiofarmaka banyak dimanfaatkan untuk berbagai diagnosa penyakit dan juga untuk pengobatan.

Pengertian sediaan farmasi menurut Undang-Undang Republik Indonesia Nomor 36 Tahun 2009 tentang Kesehatan Pasal 1 ayat (9) adalah obat, bahan obat, obat tradisional dan kosmetika. Kemudian Pasal 98 ayat (1) sediaan farmasi harus aman, berkhasiat/bermanfaat, bermutu dan terjangkau. Sedangkan pengertian obat menurut Undang-undang Kesehatan adalah bahan atau paduan bahan, termasuk produk biologi yang diigunakan untuk mempengaruhi atau menyelidiki sistem fisiologi atau keadaan patologi dalam rangka penetapan diagnosis, pencegahan, penyembuhan, pemulihan, peningkatan kesehatan dan kontrasepsi, untuk manusia.

Dari pasal diatas dapat dijelaskan bahwa radiofarmaka adalah sediaan farmasi berupa obat yang telah ditandai dengan zat radioaktif. Dikatakan sebagai obat karena radiofarmaka digunakan untuk keperluan penetapan diagnosa dan pengobatan suatu penyakit dan diberikan kepada pasien melalui oral, parental maupun inhalasi.

Radiofarmaka yang banyak digunakan untuk tujuan diagnostik di pelayanan Kedokteran Nuklir di seluruh Indonesia adalah farmaka yang bertanda radionuklida yang dihasilkan dari generator ${ }^{99} \mathrm{Mo} /{ }^{99 \mathrm{~m}} \mathrm{Tc}$ berupa senyawa teknesium-99m. Radionuklida ini memiliki sifat fisika dan kimia yang ideal untuk tujuan diagnostik.

Tujuan pengobatan atau terapi radiasi internal dengan radiofarmaka adalah untuk kuratif yaitu menghilangkan (eradikasi) tumor pada daerah lokal dan kelenjar getah bening regional, dengan tujuan meningkatkan angka kelangsungan hidup dengan meningkatnya kontrol lokal, terutama dilakukan pada kanker ukuran kecil. Tujuan kedua adalah paliatif yaitu untuk menghilangkan gejala yang ada dengan harapan dapat meningkatkan kualitas hidup penderita. Biasanya diberikan pada kanker stadium lanjut, misalnya untuk menghilangkan nyeri pada kanker 
yang telah menyebar pada tulang. Berbagai jenis radionuklida banyak digunakan untuk terapi antara lain larutan Nal-131 untuk terapi karsinoma tiroid atau ${ }^{89} \mathrm{Sr}$ (strontium) untuk terapi paliatif pada metastasis tulang. Sama seperti halnya generator ${ }^{99} \mathrm{Mo} /{ }^{99 \mathrm{~m}} \mathrm{Tc}$, larutan Nal-131 untuk pengobatan tiroid yang banyak di gunakan dipelayanan kedokteran nuklir disuplai dari PT. BATAN TEKNOLOGI.

\section{Penggunaan Radiofarmaka yang Aman}

Beberapa aspek yang harus diperhatikan sebelum radiofarmaka diberikan kepada pasien. Yang pertama adalah bahwa radiofarmaka agar aman digunakan oleh pasien maka harus dibuat dengan berpedoman pada Cara Pembuatan Obat Yang Baik (CPOB), baik di industri farmasi ataupun di pelayanan Kedokteran Nuklir. Hal ini sangat penting bahwa pasien menerima obat yang bermutu tinggi. Seperti dinyatakan dalam Undang-Undang Republik Indonesia Nomor 36 Tahun 2009 tentang Kesehatan Bagian kelima belas mengenai Pengamanan Sediaan Farmasi dan Alat Kesehatan yang tertera pada Pasal 98 ayat (1) menyatakan bahwa: sediaan farmasi dan alat kesehatan harus aman, berkhasiat/bermanfaat, bermutu, dan terjangkau.

Selanjutnya dijelaskan di dalam Peraturan Pemerintah Republik Indonesia Nomor 72 tahun 1998 tentang Pengamanan Sediaan Farmasi dan Alat Kesehatan pada pada Pasal 2 bahwa sediaan farmasi yang diproduksi dan/atau diedarkan harus memenuhi persyaratan mutu, keamanan, dan kemanfaatan. Dapat dikatakan bahwa radiofarmaka tidak berbeda dengan sediaan farmasi konvensional lainnya dalam persyaratan mutu, keamanan dan manfaatnya yang membedakannya adalah adanya unsur radioaktif di dalam senyawanya. Dengan demikian, semua produk radiofarmaka harus melalui perlakuan kendali mutu yang ketat. Standar mutu dan standar kemurnian harus ditetapkan dan produk ini harus diuji untuk menjamin kesesuaiannya terhadap standar tersebut. Kendali mutu mengacu pada standar pembuatan obat Farmakope Indonesia, British Farmakope atau US Farmakope sehingga ada jaminan kepastian bahwa obat itu aman digunakan.

Dalam proses produksi sama seperti sediaan farmasi konvensional harus mengikuti Cara Pembuatan obat yang baik (CPOB) bertujuan untuk menjamin obat dibuat secara konsisten, memenuhi persyaratan yang ditetapkan dan sesuai dengan tujuan penggunaannya. CPOB mencakup seluruh aspek produksi dan pengendalian mutu. Uraian yang diberikan dalam pedoman ini memberikan petunjuk yang benar untuk unit pembuatan dalam skala besar, laboratorium radiofarmasi terpusat dan laboratorium radiofarmasi rumah sakit.

Selain itu Pedoman GMP (Good Manufacturing Practises) atau Cara Pembuatan Obat yang Baik (CPOB) telah dikembangkan oleh Organisasi Kesehatan Dunia (World Health Organization, WHO) yang merupakan hasil kerjasama dengan Badan Tenaga Atom Internasional (International Atomic Energy Agency, IAEA). Adapun pedoman tersebut ditujukan untuk pengawasan penyiapan radioafarmaka di rumah sakit, penyiapan radiofarmaka dalam pusat radiofarmasi, produksi radiofarmaka dalam pusat dan institut nuklir atau oleh pabrik industri, agar produk yang dihasilkan dapat memenuhi spesifikasi yang telah ditentukan.

Sediaan radiofarmaka yang digunakan di pelayanan Kedokteran Nuklir umumnya merupakan sediaan injeksi steril dan apirogenik. Untuk menjamin keamanan pengunaan radiofarmaka, sediaan radiofarmaka dipersiapkan di rumah sakit dengan cara aseptik dan memenuhi persyaratan farmakologis lainnya. Namun sampai dengan saat ini Pemerintah dalam hal ini Badan Pemeriksaan Obat dan Makanan sendiri yang bertugas mengawasi dan mengatur mengenai obat-obatan belum mengeluarkan pedoman bagi Cara Pembuatan Radiofarmaka yang Baik di Industri maupun di rumah sakit.

Aspek kedua yang harus diperhatikan adalah adanya paparan radiasi dari sediaan radiofarmaka yang digunakan oleh pasien. Radiofarmaka berbeda dengan sediaan farmasi konvensional lainnya karena radiofarmaka mengandung senyawa radionuklida yang bersifat 
radioaktif. Perlu diingat bahwa semua persyaratan yang ditentukan bagi larutan parenteral (injeksi) tetap harus dipenuhi oleh radiofarmaka, misalnya syarat sterilitas, toksisitas, pirogenitas dan syarat lainnya. Namun demikian dengan adanya bagian radioaktif maka diperlukan tambahan syarat dan pengetahuan agar radiofarmaka yang dibuat dapat ditangani dengan aman dan dapat digunakan oleh pasien secara efektif.

Sifat radioaktif pada Radionuklida mengharuskan adanya beberapa syarat dalam memilih Radionuklida yang digunakan untuk tujuan diagnostik ataupun untuk terapi. Dosis radiasi yang diserap atau jumlah energi yang dialihkan ke sel-sel jaringan, menjadi pertimbangan suatu radiofarmaka. Untuk dapat lebih mengurangi dosis radiasi pada organ tubuh maka radiofarmaka untuk tujuan diagnostik harus cepat dilepaskan oleh komponen darah (waktu paruh darah pendek), dengan cepat diakumulasi oleh organ yang akan diperiksa (waktu paruh akumulasi pendek), dan kemudian dikeluarkan dari dalam organ tubuh dan diekskresi (waktu paruh eliminasi relatif pendek). Sebaliknya radiofarmaka untuk terapi harus cepat terakumulasi secara spesifik oleh bagian yang akan diterapi (waktu paruh akumulasi pendek), dimetabolisme, namun tetap tinggal di dalam sel kanker selama mungkin (waktu paruh eliminasi panjang).

\section{Pengawasan Penggunaan Radiofarmaka}

Penggunaan sumber radiasi dan produk senyawa bertanda (Radiofarmaka) untuk berbagai kepentingan telah diatur oleh lembaga yang berwenang di semua Negara di seluruh dunia. Namun demikian sampai dengan saat ini di Indonesia lembaga yang berwenang dalam pengawasan obat-obatan dalam hal ini Badan POM, belum mengatur dan mengawasi mengenai penggunaan radiofarmaka. Di Amerika Serikat pengaturan terhadap radiofarmaka telah dimulai pada tahun 1975, lembaga yang berwenang dalam mengawasi Obat dan Makanan yaitu FDA telah menetapkan suatu peraturan yang mengatur manfaat klinis radiofarmaka. Jadi FDA mengatur mengenai keamanan dan khasiat dari sediaan radiofarmaka pada manusia sedangkan pengaturan mengenai proteksi radiasi bagi para pekerja radiasi, pasien dan masyarakat umum dilakukan oleh Nuclear Regulatory Commission (NRC).

Di Indonesia untuk mengawasi kegiatan yang berkaitan dengan pemanfaatan dan bahaya radiasi yang ditimbulkan oleh tenaga nuklir adalah Badan Pengawas Tenaga Nuklir (BAPETEN). Badan ini berwenang mengeluarkan ketentuan-ketentuan di bidang keselamatan kerja radiasi, dengan sasaran tercapainya tertib hukum dalam pemanfaatan tenaga nuklir di semua bidang.

Seperti yang tercantum didalam Undang-Undang Republik Indonesia Nomor 36 Tahun 2009 tentang Kesehatan pasal 3 dinyatakan bahwa Pembangunan kesehatan bertujuan meningkatkan kesadaran, kemauan, dan kemapuan hidup sehat bagi setiap orang agar terwujud derajat kesehatan masyarakat yang setinggi-tingginya, sebagai investasi bagi pembangunan sumber daya manusia yang produktif secara sosial dan ekonomis. Dari penjelasan pasal tersebut, maka penggunaan Radiofarmaka di rumah sakit melalui pelayanan kedokteran nuklir untuk tujuan diagnosa dan terapi adalah sesuai dengan pembangunan kesehatan yang bertujuan untuk meningkatkan derajat kesehatan masyarakat.

Pemerintah sendiri telah mengatur penggunaan sediaan farmasi konvensional di dalam Undang-Undang Kesehatan No.36 tahun 2009 tentang Kesehatan pada Pasal 98 ayat (1) yang menyatakan bahwa Sediaan farmasi dan alat kesehatan harus aman, berkhasiat/bermanfaat, bermutu, dan terjangkau. Sedangkan Sediaan Farmasi menurut Undang-undang No.36 tahun 2009 tentang Kesehatan dalam Pasal 1 ayat (4) adalah obat, obat tradisional, dan kosmetika. Sedangkan definisi obat menurut Undang-Undang adalah bahan atau paduan bahan, termasuk produk biologi yang diigunakan untuk mempengaruhi atau menyelidiki sistem fisiologi atau keadaan patologi dalam rangka penetapan diagnosis, pencegahan, penyembuhan, pemulihan, peningkatan kesehatan dan kontrasepsi, untuk manusia. 
Pengamanan sediaan farmasi dan alat kesehatan merupakan upaya dalam pembangunan kesehatan yang dilakukan untuk melindungi masyarakat dari bahaya yang disebabkan oleh penggunaan sediaan farmasi dan alat kesehatan yang tidak tepat. Sebagai pelaksanaan UndangUndang Republik Indonesia Nomor 23 Tahun 1992 tentang Kesehatan maka di buat Peraturan Pemerintah Republik Indonesia Nomor 72 Tahun 1998 tentang Pengamanan Sediaan Farmasi dan Alat Kesehatan. Dalam peraturan ini diatur pula mengenai persyaratan mutu, keamanan dan kemanfaatan, produksi, peredarah dan penyerahan sediaan farmasi.

Perlindungan hukum bagi konsumen terhadap bahaya penggunaan barang yang dikonsumsinya telah diatur di dalam Undang-Undang Republik Indonesia Nomor 8 Tahun 1999 tentang Perlindungan Konsumen. Lahirnya Undang-Undang ini memberikan harapan bagi masyarakat Indonesia untuk memperoleh perlindungan atas kerugian yang diderita dari suatu barang atau jasa. Undang-Undang Perlindungan Konsumen menjamin kepastian hukum bagi konsumen terhadap pemakaian barang dalam hal ini obat-obatan.

Dari penjelasan diatas jelas bahwa berbagai peraturan telah dibuat dengan tujuan untuk mencapai mutu yang tinggi dari obat-obatan yang diedarkan dan untuk mencapai keamanan penggunaan obat tersebut bagi pemeliharaan atau meningkatkan derajat kesehatan masyarakat. Radiofarmaka adalah obat karena merupakan bahan yang digunakan untuk menyelidiki sistem fisiologi tubuh dalam penetapan diagnosis dan penyembuhan. Sebagai obat, seperti sediaan farmasi pada umumnya, sediaan radiofarmaka sebelum dapat digunakan untuk pengobatan pasien, terlebih dahulu harus lolos berbagai rangkaian uji kualitas dengan persyaratan yang telah ditentukan yang mengacu pada standar yang telah ditetapkan dalam buku farmakope atau buku standard lainnya yang ditetapkan oleh Menteri. Disamping itu, karena radiofarmaka merupakan zat radioaktif, aturan prinsip proteksi radiasi yang ditetapkan Badan Pengawas Tenaga Nuklir Nasional juga harus diikuti, sehingga ada kepastian jaminan keamanan bagi petugas maupun pasien terhadap efek radiasi yang ditimbulkan. Namun demikian sampai saat ini belum ada satu peraturan yang spesifik untuk mengatur penggunaan radiofarmaka, hal ini sangat diperlukan agar memberi perlindungan hukum bagi pasien yang menggunakannya.

\section{B. Asas Keamanan Penggunaan Obat}

Obat merupakan suatu produk yang diproduksi oleh pabrik obat dengan harus mengikuti Cara Pembuatan Obat yang Baik di dalam memproduksinya. Sebelum diedarkan dimasyarakat, pabrik pembuat harus mendaftarkan produknya ke Departemen Kesehatan RI melalui Badan Pemeriksaan Obat dan Makanan (BPOM). Dalam pendaftaran tersebut harus tercantum data obat misalnya tentang: efektivitas, dosis, cara penggunaan, efek samping, stabilitas sediaan dan lain-lain. Bila data telah lengkap dan memenuhi syarat yang telah ditentukan, barulah produk akan mendapat nomor regristrasi. Setelah obat mendapat izin edar, obat akan di distribusikan atau diedarkan dengan cara distribusi obat yang baik. Dengan kata lain obat yang diedarkan tersebut "aman" dalam penggunaannya.

Aspek pemantauan keamanan obat secara terus menerus merupakan hal yang sangat penting di lakukan terhadap semua obat yang di produksi oleh Industri Farmasi terutama ketika obat tersebut digunakan secara luas oleh masyarakat. Pemerintah melalui lembaga yang berwenang dalam pengaturan dan pengawasan dalam hal ini Badan Pengawas Obat dan Makanan Republik Indonesia mempunyai tanggung jawab kepada masyarakat untuk menjamin bahwa semua produk obat yang beredar adalah memenuhi persyaratan aman, kemanfaatan dan bermutu. Hal ini sesuai dengan asas keamanan penggunaan obat yakni memberikan jaminan keamanan dalam penggunaan, pemakaian dan pemanfaatan obat yang dikonsumsi atau digunakan oleh pasien. Agar obat yang digunakan oleh konsumen sesuai dengan asas keamanan penggunaan obat maka harus dilakukan pengawasan produksi obat dan peredaran obat tersebut. 
Dalam kaitan dengan pengawasan produksi obat yang bermutu maka Badan POM telah mensyaratkan bahwa obat harus diproduksi menurut Cara Produksi Obat yang Baik. CPOB menyangkut seluruh aspek produksi dan pengendalian mutu dan bertujuan untuk menjamin bahwa obat yang dibuat senantiasa memenuhi persyaratan mutu yang telah ditentukan sesuai dengan tujuan penggunaannya. Industri Farmasi wajib menerapkan Cara Pembuatan Obat yang Baik (CPOB) dalam seluruh aspek dan rangkaian kegiatan pembuatan obat hal ini tertuang dalam Surat Keputusan Kepala Badan Pengawas Obat dan Makanan Republik Indonesia Nomor HK.00.05.3.0027 tahun 2006 tentang Penerapan Pedoman Cara Pembuatan Obat yang Baik. Industri farmasi yang telah memenuhi persyaratan $\mathrm{CPOB}$ akan diberikan sertifikat $\mathrm{CPOB}$ yang diperinci untuk setiap bentuk sediaan. Selanjutnya penerapan CPOB ini merupakan salah satu kriteria agar obat memiliki izin edar. Dengan demikian obat harus dibuat mengikuti cara produksi obat yang baik sehingga terpenuhinya asas keamanan penggunaan obat.

Sedangkan penyaluran atau penyerahan sediaan farmasi dari Industri farmasi sampai ke tangan konsumen harus dilaksanakan dengan Cara Distribusi Obat Yang Baik (CDOB). Cara distribusi obat yang baik dalam peredaran obat dapat memberikan jaminan keamanan penggunaan obat oleh konsumen. Hal ini tertuang di dalam Keputusan Kepala Badan Pengawas Obat dan Makanan Republik Indonesia Nomor: HK. 00.05.3.2522 tahun 2003 tentang Penerapan Pedoman Cara Distribusi Obat Yang Baik.

Peredaran setiap obat erat kaitannya dengan izin edar dimana sediaan farmasi yang akan diedarkan kedalam dan dikeluarkan dari wilayah Indonesia harus memiliki izin edar seperti telah diatur dalam Undang-Undang Republik Indonesia Nomor 36 Tahun 2009 tentang Kesehatan menyatakan bahwa sediaan farmasi hanya dapat diedarkan setelah mendapat izin edar.

Pemerintah berwenang mancabut izin edar dan memerintahkan penarikan dari peredaran sediaan farmasi dan alat kesehatan yang telah memperoleh izin edar, yang kemudian terbukti tidak memenuhi persyaratan mutu dan/atau keamanan dan/atau kemanfaatan, dapat disita dan dimusnahkan sesuai dengan ketentuan peraturan perundang-undangan.

Peraturan Pemerintah Republik Indonesia Nomor 72 tahun 1998 tentang Pengamanan Sediaan Farmasi dan Alat Kesehatan juga menjelaskan bahwa sediaan farmasi hanya dapat diedarkan setelah memperoleh izin edar dari Menteri dan menyatakan izin edar sediaan farmasi diberikan atas dasar permohonan secara tertulis kepada menteri.

Semua produk obat yang beredar di pasaran Indonesia wajib diregistrasi di Badan Pengawas Obat dan Makanan (Badan POM melalui tahapan evaluasi meliputi aspek keamanan, kualitas, dan kemanfaatan yang berkaitan dengan produk tersebut. Untuk itu tentunya diperlukan sistem evaluasi dengan menggunakan perangkat keras, perangkat lunak dan keahlian serta kehandalan Sumber Daya Manusia. Oleh karena itu, semua produk yang telah lolos dievaluasi oleh Badan POM akan mendapatkan ijin edar melalui perolehan nomor registrasi.

Izin edar suatu produk sangatlah penting dalam suatu sistem pengawasan obat hal ini dilakukan untuk mencapai pemastian mutu, khasiat dan keamanan obat yang diedarkan diwilayah Indonesia agar sesuai dengan asas keamanan penggunaan obat yakni memberikan jaminan keamanan dalam penggunaan, pemakaian dan pemanfaatan obat yang dikonsumsi atau digunakan oleh pasien.

\section{HUBUNGAN ANTARA PENGGUNAAN RADIOFARMAKA UNTUK DIAGNOSA DAN TERAPI DI INDONESIA DAN ASAS KEAMANAN PENGGUNAAN OBAT}

Penggunaan Radiofarmaka untuk Diagnosa dan terapi Pemanfaatan atau penggunaan sumber radiasi pengion dalam bentuk radioisotop (radionuklida) dan senyawa bertanda radioaktif (radiofarmaka) di Indonesia di mulai tidak lama setelah peresmian reaktor nuklir di Bandung pada tahun 1965. Sampai dengan saat ini penggunaan dan jenis radiofarmaka yang 
digunakan di bidang Kedokteran Nuklir berkembang secara terus menerus, hal ini juga disebabkan dibangunnya fasilitas pelayanan Kedokteran Nuklir di beberapa rumah sakit di Indonesia.

Produk radiofarmasi (radiofarmaka) yang banyak digunakan di kedokteran nuklir meliputi: generator radionuklida, komponen non radioaktif ("kits" atau disebut farmaka) yang digunakan untuk menyiapkan senyawa bertanda dan produk radioaktif siap pakai yang biasanya digunakan untuk terapi radiasi internal.

Makin meningkatnya penggunaan radiofarmaka baik untuk tujuan diagnostik maupun terapi, hal ini tentunya sejalan dengan tujuan pembangunan kesehatan yang bertujuan meningkatkan kesadaran, kemauan dan kemampuan hidup sehat bagi setiap orang agar terwujud derajat kesehatan masyarakat yang setinggi-tingginya.

Seperti tercantum di dalam Undang-undang Republik Indonesia Nomor 36 tahun 2009 tentang Kesehatan pada pasal 1 ayat (4) bahwa: "Sediaan Farmasi adalah obat, bahan obat, obat tradisional, dan kosmetika". Dalam Undang Undang Kesehatan yang dimaksud obat adalah:" bahan atau paduan bahan, termasuk produk biologi yang diigunakan untuk mempengaruhi atau menyelidiki sistem fisiologi atau keadaan patologi dalam rangka penetapan diagnosis, pencegahan, penyembuhan, pemulihan, peningkatan kesehatan dan kontrasepsi, untuk manusia". Dari pasal ini dapat dijelaskan bahwa sediaan radiofarmaka merupakan obat oleh karena di gunakan untuk menyelidiki sistem fisiologi dalam rangka penetapan diagnosis dan penyembuhan.

Seperti sediaan farmasi lainnya sediaan radiofarmaka sebelum dapat digunakan untuk pengobatan pasien, terlebih dahulu harus lolos berbagai rangkaian uji kualitas dengan persyaratan yang telah ditentukan yang mengacu pada standar yang telah ditetapkan dalam buku farmakope atau buku standar lainnya yang ditetapkan oleh Menteri. Proses pembuatan radiofarmaka baik di industri maupun di pelayanan kedokteran nuklir harus mengikuti pedoman Cara Pembuatan Obat yang Baik (POB). Dengan demikian radiofarmaka yang digunakan memenuhi persyaratan, keamanan, mutu dan kemanfaatan. Hal ini sesuai dengan asas keamanan penggunaan obat yakni memberikan jaminan keamanan dalam penggunaan, pemakaian dan pemanfaatan obat yang dikonsumsi atau digunakan oleh pasien.

Disamping itu, karena radiofarmaka merupakan zat radioaktif, aturan prinsip proteksi radiasi yang ditetapkan Badan Pengawas Tenaga Nuklir Nasional juga harus diikuti, sehingga ada kepastian jaminan keamanan bagi petugas maupun pasien terhadap efek radiasi yang ditimbulkan. Hal ini telah ditetapkan dalam Undang-Undang Republik Indonesia Nomor 10 Tahun 1997 tentang Ketenaganukliran yang ditujukan untuk mengawasi seluruh pemanfaatan tenaga nuklir.

Undang-Undang tentang Kesehatan sebagai landasan hukum dalam pembangunan kesehatan telah memberikan arah pengaturan guna tercapainya kesadaran, keamanan, dan kemampuan untuk hidup sehat bagi setiap orang agar dapat mewujudkan derajat kesehatan yang optimal, yang dilakukan melalui upaya-upaya kesehatan yang didukung oleh sumber daya kesehatan. Salah satu bentuk upaya kesehatan dalam rangka mewujudkan derajat kesehatan yang optimal adalah pengamanan sediaan farmasi dan alat kesehatan.

Sebagai peraturan pelaksanaan dari Undang-Undang Republik Indonesia Nomor 23 Tahun 1992 tentang Kesehatan, Peraturan Pemerintah Republik Indonesia No.78 tahun 1998 tentang Pengamanan Sediaan Farmasi dan Alat Kesehatan disusun untuk memberi kejelasan, penjabaran, dan pedoman serta kepastian dan perlindungan hukum bagi penyelenggaraan upaya kesehatan mengenai pengamanan sediaan farmasi dan alat kesehatan. Pengamanan sediaan farmasi dan alat kesehatan dilakukan untuk melindungi masyarakat dari bahaya yang disebabkan oleh penggunaan sediaan farmasi dan alat kesehatan yang tidak tepat dan/atau yang tidak memenuhi 
persyaratan mutu, keamanan, dan kemanfaatan. Selain hal tersebut, sediaan farmasi dan alat kesehatan perlu dijamin ketersediaannya yang tersebar secara merata dan terjangkau sesuai dengan kebutuhan masyarakat dalam rangka pemeliharaan dan peningkatan derajat kesehatan masyarakat. PP 72 mengatur pula mengenai persyaratan mutu, keamanan dan kemanfaatan sediaan farmasi serta produksi peredaran dan izin edar sediaan farmasi.

Seperti telah kita ketahui bahwa izin edar adalah bentuk persetujuan regristrasi obat untuk dapat diedarkan di wilayah Indonesia. Pemerintah telah membuat semua produk obat yang beredar di pasaran Indonesia wajib diregistrasi di Badan Pengawas Obat dan Makanan (BPOM). Dengan demikian, semua produk yang diregistrasi akan melalui tahapan evaluasi oleh BPOM meliputi aspek keamanan, kualitas, dan kemanfaatan yang berkaitan dengan produk tersebut. Semua produk yang telah lolos dievaluasi oleh BPOM akan mendapatkan ijin edar melalui perolehan nomor registrasi.

Radiofarmaka adalah obat yang dalam proses produksi dan peredarannya harus memenuhi ketentuan seperti sediaan farmasi lainnya yang mana telah diatur dalam UndangUndang Republik Indonesia Nomor 36 Tahun 2009 tentang Kesehatan dan Peraturan Pemerintah Republik Indonesia Nomor 72 Tahun 1998 tentang Pengamanan Sediaan Farmasi dan Alat Kesehatan. Namun demikian sampai saat ini belum ada satu peraturan yang spesifik untuk mengatur penggunaan radiofarmaka, bagaimana pedoman Cara Pembuatan Radiofarmaka yang Baik, Cara Distribusi Radiofarmaka yang Baik serta tata cara regristrasi sediaan radiofarmaka, hal ini sangat diperlukan untuk melindungi pasien yang menggunakan radiofarmaka di pelayanan kedokteran nuklir agar terhindar dari bahaya yang disebabkan oleh penggunaan sediaan radiofarmaka yang tidak tepat dan/atau yang tidak memenuhi persyaratan mutu, keamanan, dan kemanfaatan.

\section{PENUTUP}

\section{A. Kesimpulan}

Berdasarkan uraian dalam Bab Hasil Penelitian dan Pembahasan pada penelitian tesis ini dapat disimpulkan beberapa kesimpulan, yaitu sebagai berikut:

1. Penggunaan Radiofarmaka melalui tehnik Kedokteran Nuklir dapat digunakan untuk tujuan diagnostik, terapi dan penelitian kedokteran untuk mempelajari perubahan fisiologi dan biokimia. Produk radiofarmaka yang banyak digunakan di kedokteran nuklir di Indonesia meliputi: generator radionuklida, komponen non radioaktif ("kits" atau disebut farmaka) yang digunakan untuk menyiapkan senyawa bertanda dan produk radioaktif siap pakai yang biasanya digunakan untuk terapi radiasi internal. Seperti sediaan farmasi lainnya, radiofarmaka sebelum digunakan oleh pasien harus melewati berbagai uji kendali kualitas sesuai dengan standar yang telah ditetapkan. Proses pembuatan radiofarmaka baik di industri maupun di pelayanan kedokteran nuklir harus mengikuti pedoman Cara Pembuatan Obat/Radiofarmaka yang Baik (CPO/RB). Demikian pula distribusi produk radiofarmaka (generator radionuklida dan produk radioaktif siap pakai untuk terapi radiasi internal) dari Pabrik pembuat ke Kedokteran Nuklir dengan menggunakan jaringan lalu lintas umum, baik melalui darat, air maupun udara, dilakukan dengan memenuhi ketentuan keselamatan radiasi. Sehingga radiofarmaka yang digunakan untuk tujuan diagnosa dan terapi di Kedokteran Nuklir sesuai dengan asas keamanan penggunaan obat yakni dapat memberikan jaminan keamanan dalam penggunaan, pemakaian dan pemanfaatan obat yang dikonsumsi atau digunakan oleh pasien.

2. Asas keamanan penggunaan obat adalah memberikan jaminan keamanan dalam penggunaan, pemakaian dan pemanfaatan obat yang dikonsumsi atau digunakan oleh pasien. Untuk menjamin bahwa obat yang digunakan oleh konsumen sesuai dengan asas 
keamanan obat maka setiap obat yang di produksi oleh Industri Farmasi harus mengikuti pedoman Cara Pembuatan Obat yang Baik (CPOB). Selanjutnya untuk melindungi masyarakat dari kesalahan penggunaan dan penyalahgunaan serta menjamin keabsahan dan mutu obat serta agar obat yang sampai ke konsumen adalah obat yang efektif, aman dan dapat digunakan sesuai tujuan penggunaannya maka penyaluran obat harus mengikuti Cara Distribusi Obat yang Baik (CDOB). Selain itu untuk mencapai pemastian mutu, khasiat dan keamanan obat yang diedarkan diwilayah Indonesia maka setiap produk obat wajib diregistrasi di Badan Pengawas Obat dan Makanan (Badan POM) dan produk yang telah lolos dievaluasi oleh Badan POM akan mendapatkan ijin edar melalui perolehan nomor registrasi.

3. Penggunaan radiofarmaka di kedokteran nuklir memerlukan pengawasan. Selain memberikan keuntungan bagi kesehatan dapat pula memberikan dampak kepada pasien, petugas radiasi dan lingkungan sekitarnya sebagai akibat paparan radiasi radiofarmaka tersebut. Pemerintah berdasarkan Undang-Undang Republik Indonesia Nomor 10 Tahun 1997 tentang Ketenaganukliran, mengawasi seluruh pemanfaatan tenaga nuklir termasuk penggunaan radiofarmaka yang digunakan di kedokteran nuklir. Pengawasan dilakukan dengan cara pembentukan peraturan, perizinan dan pelaksanaan inspeksi, sehingga dapat memberi perlindungan hukum bagi para pekerja radiasi, masyarakat dan lingkungan sekitarnya. Namun demikian baik Undang-Undang Ketenaganukliran maupun peraturanperaturan pelaksananya tidak mengatur secara spesifik mengenai persyaratan mutu, keamanan dan kemanfaatan penggunaan radiofarmaka, produksi dan peredaran radiofarmaka.

4. Undang-Undang Republik Indonesia No.36 tahun 2009 tentang Kesehatan telah mengatur mengenai pengamanan sediaan farmasi. Sebagai pelaksanaan Undang-Undang Republik Indonesia Nomor 23 tahun 1992 maka di buat Peraturan Pemerintah Republik Indonesia Nomor 72 tahun 1998 tentang Pengamanan Sediaan Farmasi dan Alat Kesehatan. Dalam peraturan ini diatur pula mengenai persyaratan mutu, keamanan dan kemanfaatan, produksi, peredaran dan penyerahan sediaan farmasi. Namun dalam peraturan-peraturan tersebut tidak dijelaskan mengenai pengaturan untuk sediaan Radiofarmaka mengingat bahwa sediaan tersebut juga merupakan senyawa obat yang digunakan untuk penetapan diagnosa dan juga pengobatan.

\section{B. SARAN}

Berdasarkan hasil penelitian dan pembahasan hasil penelitian serta kesimpulan, maka ada beberapa saran hal ini mengingat bahwa:

1. Penggunaan dan jenis radiofarmaka dalam bidang kedokteran Nuklir di Indonesia sampai dengan saat ini belum memiliki regulasi untuk radiofarmaka. Oleh karena itu penulis menyarankan agar di buat peraturan khusus untuk mengawasi pengggunaan sediaan radiofarmaka yang meliputi proses pembuatan (produksi), peredaran dan tata cara regristrasi, sehingga dapat memberikan jaminan bahwa produk radiofarmaka yang adalah memenuhi persyaratan aman, kemanfaatan dan bermutu. Hal ini sesuai dengan asas keamanan penggunaan obat yakni memberikan jaminan keamanan dalam penggunaan, pemakaian dan pemanfaatan obat yang dikonsumsi atau digunakan oleh pasien.

2. Sebaiknya ada kerjasama antara organisasi profesi seperti Perhimpunan Kedokteran Nuklir Indonesia (PKNI) dengan Badan POM dan Badan Pengawas Tenaga Nuklir (BAPETEN) mengingat hal ini sangat membantu untuk pertukaran informasi, penelitian dan pengembangan di lapangan yang memfasilitasi keberterimaan radiofarmaka. Selain itu rekomendasi atau pedoman yang telah dikeluarkan oleh Badan Internasional Nuklir seperti IAEA juga dapat digunakan sebagai acuan untuk menyiapakan regulasi nasional. 
3. Pada saat ini telah banyak rumah sakit di seluruh Indonesia yang telah memiliki pelayanan kedokteran nuklir. Namun demikian agar masyarakat lebih memahami dan mengetahui manfaat penggunaan radiofarmaka sebagai penunjang diagnostik dan pengobatan maka perlu adanya informasi hasil evaluasi penggunaan radiofarmaka serta efek samping yang ditimbulkannya yang dapat diwujudkan dalam bentuk artikel, brosur dan sebagainya.

\section{DAFTAR PUSTAKA}

Batan, Pedoman Tentang Cara Pembuatan Radiofarmaka Yang Baik, Serpong, Batan Tenaga Nuklir Nasional, 2008.

Soejono Soekanto, et al, Penelitian Hukum Normatif, Jakarta Rajawali, Tahun 1995.

Hilman Hadikusuma, Metode Pembuatan Kertas Kerja atau Skripsi Ilmu Hukum, Mandar Maju, 1995. 